Boda, M. (2016). The impact of the 2007-2009 financial crisis on risk management in credit institutions. Copernican Journal of Finance \& Accounting, 5(2), 45-56. http://dx.doi.org/10.12775/ CJFA.2016.014

\author{
Michat BOdA* \\ Cracow University of Economics
}

\title{
THE IMPACT OF THE 2007-2009 FINANCIAL CRISIS ON RISK MANAGEMENT IN CREDIT INSTITUTIONS
}

Keywords: risk, risk management, RAPM models, hurdle rate.

J E L Classification: G19, G21, G32.

\begin{abstract}
Risk and risk management are a key aspect of the financial management of the bank. In the banking business since the mid-70s of the twentieth century, the risk continues to increase. The result of that excessive growth was the financial crisis in the years 2007-2009. Due to underestimation, lack of adequate and updated risk models, many financial institutions were on edge of bankruptcy due to insufficient funds needed to cover the losses. The financial crisis has highlighted many of the weaknesses of a regulatory nature in the functioning of the global financial system, especially the banking system. In order to reduce occurrence of future similar negative phenomena, the Basel Committee on Banking Supervision has decided to reform the banking system. As a result, Basel III was created. CRR Regulation and Directive CRD put particular emphasis on height of own funds and risk-weighted assets. All these have showed many weaknesses of the banking system, from which health and status is determined the whole economy. This paper will focus on the impact of the 2007-2009 financial crisis on risk management effectiveness in credit institutions. There will be presented the possibility of an integrated risk measurement and management. The most known methods of integrated assessment are RORAC and RAROC models, which are both used for the evaluation of the entire bank, as well as business units, or individual transactions. RORAC
\end{abstract}

Date of submission: December 27, 2016; date of acceptance: January 17, 2017.

* Contact information: bodamichal@hotmail.com, Cracow University of Economics, Rakowicka 20C/182, 31-510 Kraków, Poland, phone: +48887622580. 
and RAROC models are the basic concepts of measuring the effectiveness of risk. There will be also discussed Hurdle rate and its potential impact on the economy.

\section{INTRODUCTION}

In times of globalization and dynamic development of technology and society, the financial markets and the entire economy, constantly evolve. But sometimes those changes instead of improving the overall situation, lead to a negative outcome, which ends with a financial crisis. A very good example of this situation is the recent financial crisis of 2007-2009, which was caused, among others, by uncontrolled expansion of financial innovations, badly conducted monetary policy, the collapse of ethical and accounting standards, erroneous deregulations, and finally, excessive use of leverage (Płókarz, 2013, pp. 350-359).

All of the above factors have revealed a lot of weaknesses in the banking systems, which affected the health and overall conditions of the whole economy. Financial problems of large financial institutions have caused collapses on the stock exchanges, recessions on the financial markets and declines in the real economy (Płókarz, 2013, pp. 355-356). The financial crisis has highlighted a number of weaknesses of a regulatory nature in the functioning of the global financial system, especially the banking system. To reduce the risk of future similar negative events, a number of new regulations have been introduced, as such Basel III or Dodd-Frank Act, which have shaped the new, post-crisis model of banking and financial markets (Płókarz, 2013, pp. 350-359; Komisja Nadzoru Finansowego, 2016a).

According to the Basel III Agreement, the most important changes that can be found in the CRD IV / CRR package, include (Płókarz, 2013, p. 48; Komisja Nadzoru Finansowego, 2016a):

- changes to the CRD IV: defining issues related to corporate governance and risk management and improving the monitoring of market and credit risk by the competent supervisory authorities,

- changes in CRR: higher capital requirements, limit of leverage, more restrictive liquidity requirements.

The CRD IV and CRR regulation came into force on January $1^{\text {st }}, 2014$. The new law aims at strengthening regulation of the financial sector and create a more transparent and safer financial system (Komisja Nadzoru Finansowego, 2016b). 
The main objective of the changes that have been introduced to banks' own funds by Regulation CRR is to improve the quality of own funds. The Basel Committee on Banking Supervision has determined that the Tier I capital will be used to absorb current losses, and the purpose of Tier II capital will cater to creditors in case of bankruptcy or insolvency of the institution. Furthermore, Basel Committee on Banking Supervision has decided to abolish capital Tier III, which was used to cover risk in the trading book. Thus, the credit institution's own funds consist of capital Tier I and Tier II (Koleśnik, 2014, p. 15). CRD Directive introduces many additional buffers, such as conservation, countercyclical, G-SII, O-SII, systemic risk, which will increase the CET 1 (Koleśnik, 2014, p. 32).

Basel Committee on Banking Supervision has also regulated the leverage ratio. Since 2019, the maximum of leverage ratio will be $3 \%$ and liquidity of credit institutions in the form of Liquidity Coverage Ratio (LCR, M2), relating to the short-term liquidity and Net Stable Funding Ratio (NSFR, M4) relating to long-term liquidity (Basel Committee on Banking Supervision, 2013, 2014).

The overriding aim of the credit institution is to maximize its value while maintaining the desired relationship between the achieved financial results and risk exposures. Involvement in the balance sheet and off-balance sheet operations creates the need to identify an acceptable level of risk. The consequence of bank risk exposures are reserves, write-off of impairment, and capital. Risk management constitutes one of the basic elements of management of credit institutions, primarily in the context of the impact on the financial sector. It is a process in which in a methodical way, are solved occurring in the banking business issues with the risk in such a way that the activity as a whole and individual fields, bring sustainable avail. The risk management process consists of four successive stages (Kochaniak, 2012, pp. 239-240):

- identification - risks indication and its main sources,

- measurement - use of models and systems which are a source of information about the scale of exposure of particular units and whole institutions,

- monitoring and review - ensuring compatibility between established risk exposure and risk that occur in point of fact,

- verification - ensuring efficient and safe operation of the credit institution and effective risk management.

The risk management process subject to individual adaptation to needs of each institution. Entities with complex asset structure and significantly involved in off-balance sheet operations will have more complicated organiza- 
tional and procedural solutions. Small banks, which business scope is rather limited, use a simpler method of risk management. The scale of risk exposure decides about importance of organizational and procedural solutions and a size of regulatory or internal capital (Kochaniak, 2012, p. 241).

In accordance with the literature, and administrative division of risks in banks business, it can be distinguish two pillars of the risk:

- the first pillar - basic risks: credit risk, liquidity risk, operational risk, market risk,

- the second pillar - risk types which are particularly relevant to banks due to their business profile and these that may arise as a result of changes in economic environment, e.g. risk of reputational, business, concentration, legal, strategic, etc.

Listed above risks do not exhaust entire gamut types of risks with which we can meet in the banking business, but these ones belong to the group of the most commonly encountered in credit institutions business. All considered as substantial risk types have to find coverage in the regulatory or internal capital of a credit institution. The effectiveness of risk management determines the position of banks in the sector, while all their weaknesses are the source of potential financial and economic crises. Precisely defined and properly functioning internal organizational structure increases the safety of the entire bank. Furthermore awareness of responsibility reduces the risk resulting from mistakes (Kochaniak, 2012, pp. 243, 251-252).

\section{THE RESEARCH METHODOLOGY AND THE COURSE OF THE RESEARCH PROCESS}

As a result of a combination of these two variables, i.e. own funds and risk, a return on equity models, but also taking into account the risk involved in the ordinary course of business, are obtained. These are so-called risk adjustment performance measures (RAPM) models. Thanks to these indicators, it is possible to observe the relationship between the risk incurred by a credit institution, and the obtained effects of business activity. In the literature, there is not one a commonly used algorithm for calculating such indicators, but the formula in the general form can be represented as follows (Kałużny, 2012, p. 237):

$$
R A P M=\frac{\text { measure of income }}{\text { incur risk }}
$$


The first indicator of this group is a risk adjusted return on capital (RAROC) (Kałużny 2012, p. 237):

$$
R A R O C=\frac{\text { economic value added }}{\text { equity }} * 100 \% .
$$

Another indicator is a return on risk adjusted capital (RORAC) (Kałużny, 2012, p. 238):

$$
R O R A C=\frac{N O P A T}{\text { capital requirement }} * 100 \%
$$

where NOPAT is net operating profit after tax. In turn, the denominator is the capital requirement for which is assumed regulatory or economic capital (Kałużny, 2012, p. 238).

A combination of RAROC and RORAC is a risk-adjusted return on risk adjusted capital (RARORAC) (Kałużny, 2012, p. 238):

$$
R A R O R A C=\frac{\text { economic value added }}{\text { capital requirement }} * 100 \% .
$$

Another approach to measuring the effectiveness and risks which occurs in the literature, are top-down and bottom-up models (Iwanicz-Drozdowska, 2012, pp. 247, 252).

Top-down models assume allocation of economic or regulatory capital. These models are also called earnings volatility models, because they use Earnings at Risk. 2 basic models can be extracted (Iwanicz-Drozdowska, 2012, p. 247):

$$
\begin{aligned}
& \operatorname{RORAC}(I)=\frac{\text { return }}{\text { capital requirement } * \frac{\text { EaR of the business }}{\text { EaR of the firm }}} * 100 \% \\
& R O R A C(I I)=\frac{\text { returns-opportunity cost of regulatory capital }}{E a R} * 100 \% .
\end{aligned}
$$

In the bottom-up models for calculation of economic capital is used Value at Risk. These type of models are also known as asset volatility models. Indicators have the following form (Iwanicz-Drozdowska, 2012, pp. 252-253):

$$
R O R A C=\frac{\text { return }}{\text { economic capital }}
$$




$$
\text { RAROC }=\frac{\text { return-expected loss }}{\text { economic capital }}
$$

Based on the above information it can be concluded that there is no single, universal formula for RORAC or RAROC.

\section{THE OUTCOME OF THE RESEARCH PROCESS AND CONCLUSIONS}

RORAC indicators are presented in table 1. In this case, RORAC has been calculated as the ratio between the net profit and different heights of capital in the 9 largest credit institutions in Poland in terms of assets on a consolidated basis. In all surveyed banks can be observed decreasing trend of RORAC. This can be justified by the new regulations, i.e. Basel III, and the consequent need to increase the quantity and quality of own funds of credit institutions, and fuller risks coverage by the own funds. Furthermore as a result of these calculations can be observed how competent supervisory authorities may affect the bank's profitability adjusted for risk. In order to fulfil these requirements and maintain profitability at current levels, credit institutions may undertake various activities, such as increase capital by issuing new shares, plough current profit back, or decrease interest rate on deposits. While on the assets side they can reduce credits and loans supply in order to reduce risk-weighted assets and accordingly capital requirement, as well as rise lending rates. Additionally, it is expected employment downsizing. All these factors will affect the real economy. 


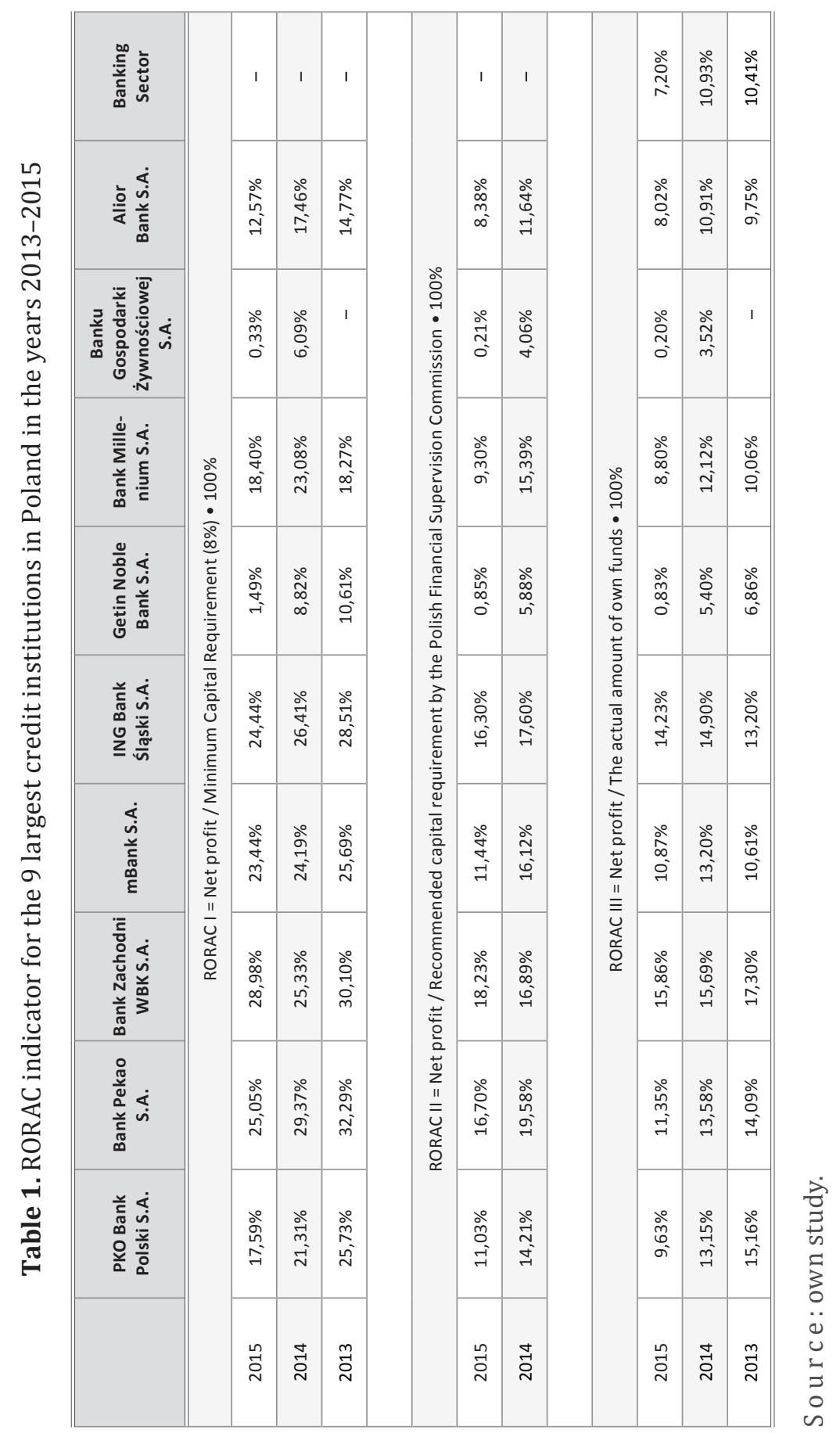


Hurdle rate represents the minimum interest rate, which should be achieved by the entity, business line or individual operations in order to create economic profit. It should be noted that the hurdle rate is also sometimes called the minimum acceptable rate of return on a project (MARR). To present how hurdle rate works, a 5 different cases are presented in table 2. In the first three cases, the dividend ratio is fixed at $30 \%$, while the requirements in respect of RWA are at a different level in each case. Depending on the risk taken by a bank and the method used for estimating RWA (standard method or internal ratings based approach), the hurdle rates (i.e. the minimum interest rate of the product) change their value. In two other cases, i.e. in the fourth and fifth, both dividend ratio and requirements in respect of RWAs are subject to change according to the principle "lower risk, lower premium" and vice versa. In this scenario, it can be observed that the type of conducted business and risks taken by credit institutions in a significant extent affect the final minimum interest rate of a new product.

Table 2. Hurdle rate -5 cases

\begin{tabular}{|c|c|c|c|c|c|}
\hline & Case 1 & Case 2 & Case 3 & Case 4 & Case 5 \\
\hline New product [PLN] & \multicolumn{5}{|c|}{100} \\
\hline Risk weighted assets [\%] & $35 \%$ & $75 \%$ & $100 \%$ & $35 \%$ & $100 \%$ \\
\hline Capital requirement [\%] & \multicolumn{5}{|l|}{$8 \%$} \\
\hline Total capital requirement [PLN] & 2,80 & 6,00 & 8,00 & 2,80 & 8,00 \\
\hline Average growth of RWAs [\%] & \multicolumn{5}{|l|}{$4,50 \%$} \\
\hline Dividend ratio [\%] & \multicolumn{3}{|l|}{$30 \%$} & $10 \%$ & $60 \%$ \\
\hline Required ROE including dividend [\%] & $6,43 \%$ & $6,43 \%$ & $6,43 \%$ & $5,00 \%$ & $11,25 \%$ \\
\hline Profit to achieve ROE [PLN] & 0,18 & 0,39 & 0,51 & 0,14 & 0,90 \\
\hline Margin required [\%] & $0,22 \%$ & $0,48 \%$ & $0,63 \%$ & $0,17 \%$ & $1,10 \%$ \\
\hline Risk Cost Margin [\%] & \multicolumn{5}{|c|}{$0,55 \%$} \\
\hline Cost Margin [\%] & \multicolumn{5}{|c|}{$1,00 \%$} \\
\hline Hurdle Rate (total margin required) [\%] & $1,77 \%$ & $2,03 \%$ & $2,18 \%$ & $1,72 \%$ & $2,66 \%$ \\
\hline
\end{tabular}

Source : own study. 
With a hypothetical credit of PLN 300,000, diminishing instalments, repayment period of 30 years, the cumulative interest on credit at an interest rate of $1.72 \%$ (case 4) amount to PLN 77,615, while at an interest rate of $2.66 \%$ (case 5) amount to PLN 120,032. The difference between total interest in these cases amounts to PLN 42,417 - on average, lower monthly instalments of around PLN 118. For example, by depositing into a savings account every month PLN 118, at an interest rate of $1.5 \%$ per annum, for 30 years, it is possible to achieve an amount of around PLN 53,607.

This simple example demonstrates how credit institutions activity, how height of RWA and potential margins, which influence on interest rates on credits, have a very large impact on the real economy and households.

The financial crisis 2007-2009 has contributed to a thorough reconstruction of legal standards regulating financial institutions. The impact of new regulation on the economy is measured by the credit channel, which implies that banks will limit the scale of lending and will increase interest rates on loans. As a consequence this will reduce aggregate demand, employment and will limit the real growth rate of GDP (Marcinkowska, 2013, pp. 119-145).

To test those effects, various studies have been conducted by regulatory and market authorities, using various methods. However, these studies have important limitations. Many assumptions have to be taken, e.g. potential reaction of banks and other market participants and the economic condition at the time of the implementation and application of new standards (Bukowski et al., 2014, pp. 62-63).

According to the Macroeconomic Assessment Group growth of the capital adequacy ratio by 1 percentage point would lead to an average decline in GDP of $0.22 \%$ after 35 quarters since the implementation of the new regulatory system. This means reducing annual GDP growth rate by $0.03 \mathrm{pp}$. Moreover, MAG research shows that an increase in the CAR by $1 \mathrm{pp}$ could lead to a decline in the effective demand for credits by $1.89 \%$, and increase in credit margins by approx. 17 basis points (Macroeconomic Assessment Group, 2010, pp. 2, 5).

Studies published by the OECD suggests the following negative effects (Cournède \& Slovik, 2011, p. 2):

- potential increase in credit margins: $15-50 \mathrm{bps}$,

- medium-term impact on economic growth: -0.05 to -0.15 pp per year.

Research of Institute of International Finance shows (Institute of International Finance, 2011, p. 12):

- an increase in the cost of credits by 281 bps over ten years, 
- an average annual decline in GDP: -0.2 pp for the years 2011 to 2020,

- reduction of jobs by 7.5 million in five years.

Data analyzed by the International Monetary Fund suggests that large banks to be able to implement the new Basel requirements, would have to increase the share of equity in total assets by $1.3 \mathrm{pp}$, which would cause the need to increase lending rates by $16 \mathrm{bps}$. The increase in lending rates would have decreased the rate of change of loans by $1.3 \%$ in the long term. The authors point out the fact that the response of banks to the new regulations will vary, depending on the relative economic development. The reason for these differences is the diversity of the cost of raising capital by banks and the price elasticity of demand for credit (Cosimano \& Hakura, 2011, p. 1).

Experts from Oxford Economics pointed out that in a number of analytical reports regarding the potential impacts of Basel III on the economy, overly optimistic assumptions are adopted, such as the effect of the credit prices (increase by $0.9-1.3 \mathrm{pp}$ ). They have also pointed to the fact that banks may increasingly focus on limiting credit in order to reduce leverage, and the financial market will not offer analogical demand for corporate bonds (Oxford Economics, 2013, pp. 1-4).

Those findings cannot be directly compared because they have been achieved by using different research methods, using various variables and performed at different times. Moreover, these studies have methodological limitations related among others to the adopted assumptions and simplifications. However, it can be concluded that the empirical studies show a negative (albeit slight) impact of new capital and liquidity regulations on economic growth (Bukowski et al., 2014, p. 68).

The financial crisis has revealed weakness in global regulation and bank risk management practices. As a result, regulators have taken steps to increase the stability of financial markets and to reduce the negative financial phenomena on the real economy. The main area of new regulations was to strengthen capital and liquidity in global banking.

The impact on financial results and balance sheets of banks will depend on:

- reallocation of capital between different business lines,

- margin policy (transfer of additional costs to customers),

- possible cost structure restructuring,

- risk appetite.

In general, there should be reduction in the risk level, but may also occur side effects, e.g. an increase in systemic risk in other, unregulated market seg- 
ments, such as shadow banking. Medium-term costs of implementation of those new regulations, and new restrictions may contribute to reducing banks' activity, and as a result to economic slowdown. The need to increase credit institutions' capital increases credit crunch risk, which may consequently lead to a decline in investment and higher unemployment.

Credit institutions which wish to achieve high revenues, have to focus on effective risk management. The key role in decision-making process could be used RAPM models and hurdle rate which will provide banks with information on how risk taken may impact on profitability (income) and, consequently, whether it is worthwhile to allocate capital in that particular project.

\section{REFERENCES}

Basel Committee on Banking Supervision (2013). Basel III: The Liquidity Coverage Ratio and liquidity risk monitoring tools. Basel. Bank for International Settlements, January, http://www.bis.org/publ/bcbs238.pdf (accessed: 31.03.2016).

Basel Committee on Banking Supervision (2014). Basel III: The Net Stable Funding ratio. Basel. Bank for International Settlements, October, http://www.bis.org/bcbs/ publ/d295.pdf (accessed: 31.03.2016).

Bukowski, S., Flejterski, S., Marcinkowska, M., Wdowiński, P., Zygierewicz, M. (2014). Wpływ regulacji sektora bankowego na wzrost gospodarczy - wnioski dla Polski. NBP. Warszawa. Instytut Ekonomiczny. Materiały i Studia, no. 305, https://www. nbp.pl/publikacje/materialy_i_studia/ms305.pdf (accessed: 05.05.2016).

Cosimano, T.F., Hakura, D.S. (2011). Bank Behavior in Response to Basel III: a Cross-Country Analysis. International Monetary Fund Working Paper. WP/11/19, May, https:// www.imf.org/external/pubs/ft/wp/2011/wp11119.pdf (accessed: 11.05.2016).

Cournède, B., Slovik, P. (2011). Macroeconomic Impact of Basel III. Organisation for Economic Co-operation and Development. Economics Department Working Papers no. 844. ECO/WKP(2011)13, February, http://www.keepeek.com/Digital-Asset-Management/oecd/economics/macroeconomic-impact-of-basel-iii_5kghwnhkkjs8-en\#page1 (accessed: 12.05.2016).

Institute of International Finance (2011). The Cumulative Impact on the Global Economy of Changes in the Financial Regulatory Framework, September, https://www.iif. com/file/7080/download?token=CwKXtHfb (accessed: 12.05.2016).

Iwanicz-Drozdowska, M. (2012). Zarządzanie finansowe bankiem. Warszawa: Polskie Wydawnictwo Ekonomiczne, wyd. III zmienione.

Kałużny, R. (2012). Ocena i analiza sytuacji majątkowo-finansowej. In Gospodarowicz A., Nosowski A. (Ed.) Zarządzanie instytucjami kredytowymi (pp. 220-238). Warszawa. Wydawnictwo C.H. Beck.

Kochaniak, K. (2012). Rodzaje ryzyka bankowego i zarządzanie nim. In A. Gospodarowicz, A. Nosowski (Ed.), Zarządzanie instytucjami kredytowymi (pp. 239-252). Warszawa: Wydawnictwo C.H. Beck. 
Koleśnik, J. (2014), Adekwatność kapitałowa banków, standardy regulacyjne. Warszawa: Wydawnictwo Difin.

Komisja Nadzoru Finansowego (2016a). Pakiet CRD IV / CRR - Historia i założenia projektu, https://www.knf.gov.pl/crd/pakiet_crd4_historia.html (accessed: 05.01.2016).

Komisja Nadzoru Finansowego (2016b). Finalny tekst tzw. pakietu CRD IV / CRR wraz ze zmianami, https://www.knf.gov.pl/finalny_tekst_pakietu.html (accessed: 17.02.2016).

Macroeconomic Assessment Group (2010). Assessing the macroeconomic impact of the transition to stronger capital and liquidity requirements - Final Report. Basel. Bank for International Settlements, December, http://www.bis.org/publ/othp12.pdf (accessed: 11.05.2016).

Marcinkowska, M. (2013). Regulation and self-regulation in banking: in search of optimum. Bank i Kredyt, 44(2), http://bankikredyt.nbp.pl/content/2013/02/ bik_02_2013_01_art.pdf (accessed: 12.05.2016).

Oxford Economics (2013). Analyzing the impact of bank capital and liquidity regulations on US economic growth. A report prepared for The Clearing House Association, April, https://www.theclearinghouse.org/ /media/files/association $\% 20$ documents/20130410\%20oxford\%20economics\%20study $\% 20$ impact $\% 20$ of $\% 20$ bank\%20capital\%20and\%20liquidity\%20regulations $\% 20$ on $\% 20$ us $\% 20$ economy. pdf (accessed: 12.05.2016).

Płókarz, R. (2013). Globalne rynki finansowe, praktyka funkcjonowania. Warszawa: Wydawnictwo Naukowe PWN. 